\title{
Urinary Microbiota; Which Non-invasive Urine Collection Method Should We Use?
}

\author{
Muhammed Selcuk Ozer ${ }^{1}$, Hüseyin Alperen Ylldız ${ }^{2}$, Canet Incir ${ }^{1}$, Dogan Deger ${ }^{3}$, Ozan \\ Bozkurt $^{1}$, Gül Ergör ${ }^{1}$, Yesim Tuncok ${ }^{1}$, Nuran Esen ${ }^{1}$, and Ahmet Adil Esen ${ }^{1}$ \\ ${ }^{1}$ Dokuz Eylul University Faculty of Medicine \\ ${ }^{2}$ Malazgirt State Hospital \\ ${ }^{3}$ Edirne Sultan Murat 1 State Hospital
}

February 20, 2021

\begin{abstract}
Objective: The aim of this study is establish the optimal non- invaszive urine sample collection method for the microbiota studies. Methodology: 12 men with bladder carcinoma underwent first voided and midstream urine collection. Urine samples were analyzed by using V3-V4 regions of bacterial 16s ribosomal RNAs. Bacterial groups with relative abundance above $1 \%$ were analyzed in first voided urine and midstream urine samples at phylum, class, order, and family level. At the genus level, all of the identified bacterial groups' relative abundances were analyzed. The statistical significance $(\mathrm{p}<0.05)$ of differences between first voided and midstream urine sample microbiota were evaluated using the Wilcoxon test. Results: According to analysis, 8 phyla, 14 class, 23 orders, 39 families, and 29 different genera were identified in the first voided and the midstream urine samples. Statistical differences were not identified between first voided and mid-stream urine samples of all bacteria groups except the Clostridiales at order level (p:0.04) and Clostridia at class level (p:0.04). Conclusions: Either first voided or midstream urine samples can be used in urinary microbiota studies as we determined that there is no statistically significant difference between them regarding the results of 16 s ribosomal RNA analysis. What's known? According to widespread acceptance, first voided urine and midstream urine should be collected separately for standard microbiologic evaluation. What's new? We found that there is no exact statistically significant difference between two collection methods even on microbiota analysis. We believe that either first voided or midstream uyrine samples can be used in urinary microbiota studies.
\end{abstract}

\section{Hosted file}

main.pdf available at https://authorea.com/users/369851/articles/510011-urinary-microbiotawhich-non-invasive-urine-collection-method-should-we-use

\section{Hosted file}

Table_1.pdf available at https://authorea.com/users/369851/articles/510011-urinarymicrobiota-which-non-invasive-urine-collection-method-should-we-use

Hosted file

Table_2.pdf available at https://authorea.com/users/369851/articles/510011-urinarymicrobiota-which-non-invasive-urine-collection-method-should-we-use 


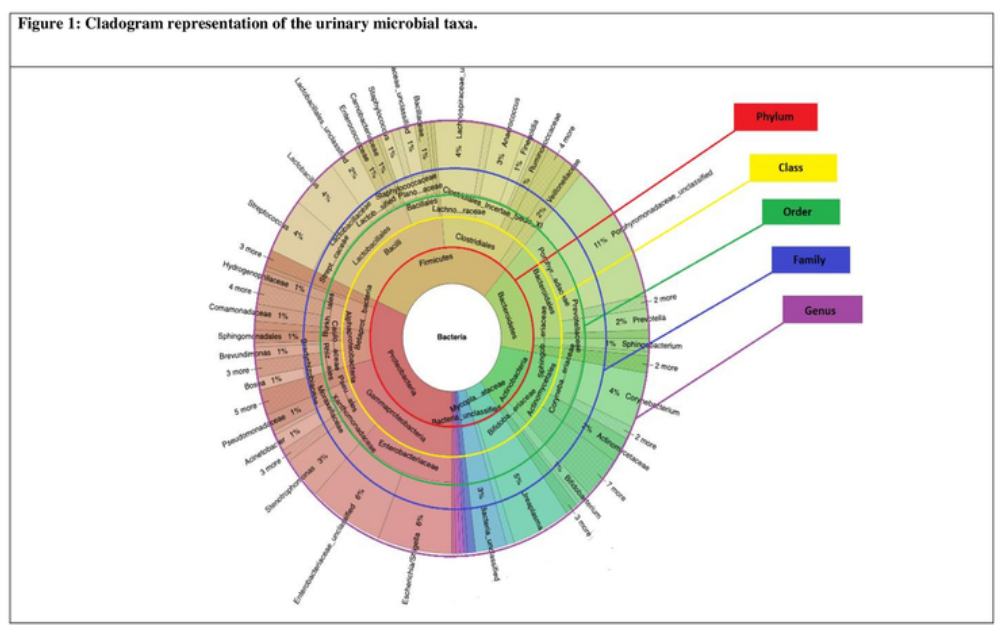

